\title{
The creation of a global market for Colombian contemporary art through valuation and match-making
}

\author{
Annatina Aerne \\ University of Lausanne, Quartier UNIL-Mouline, Bâtiment IDHEAP, CH-1015 Lausanne, Switzerland
}

\section{A B S T R A C T}

The global market for contemporary art is not quite as global, but concentrated in a few countries. This centralization notwithstanding, the Colombian art scene has achieved to internationalize to a larger extent in recent years. This article argues that two challenges make reaching a more global audience difficult: convincing international buyers of the value of art from the periphery and match-making of local sellers and international buyers. Based on these two activities, the article develops a four-fold typology of brokers that undertake either valuation, match-making, both, or none of these steps. The article identifies an empirical example corresponding to each of the ideal types, drawing on 36 semi-structured interviews with Colombian art experts. The article highlights the challenges and advantages associated with each type of brokerage. The analysis suggests that transactions are most encouraged if the party that determines the value also organizes the buyer-seller encounter. Match-makers that are not accepted valuators tend to affect the valuation of the good negatively, through their involvement in the transaction. Valuators that do not engage in match-making are helpful in establishing the value of art in Europe and the US, but it is not clear whether or not this results in transactions.

\section{Introduction}

The global market for contemporary art is not quite as global, as the term indicates, but concentrated in a few centers. The majority of art fairs takes place in Europe and the US, with most of the participating galleries from the same destinations (Quemin, 2013: 170). These galleries represent predominantly artists from their home market (Velthuis, 2013: 294), and cater to European and US collectors (SteinerLasse, Bruno, \& Resch, 2013). Certain regions thus remain underrepresented (McAndrew, 2018: 34; Quemin, 2013: 169). Colombia is not among the prominently featured countries in these international art circuits, but has received more attention recently. After a first period of increased activity in the 1950s for and by domestic actors predominantly, Colombia's art scene has seen a remarkable development in the 2000s. In contrast to this earlier flourishment, Colombia's art scene has also received increasing international attention in this recent boom.

This article argues that among others, two challenges prevent galleries ${ }^{1}$ outside Europe and the US from reaching an international audience. First, an international public needs to be convinced of the value of contemporary art from a foreign destination. A good's value must be established and accepted by the buyer before an acquisition takes place (Aspers \& Beckert, 2011; Beckert, 2009; Velthuis, 2013). This is not trivial, especially in art markets where value is based on status, rather than objective measures. An artwork's value is established in reference to the networks in which it is exhibited and traded. When the networks in which an artwork's value is established do not cover international terrain, transacting it across borders becomes difficult. Collectors trust their local gallery rather than a foreign gallery they are unfamiliar with. Bourdieu describes this with respect to literary works (Bourdieu, 2002: 4, 5; 1991: 378). The prestige of an author stays within national borders. If authors want to get recognized abroad, they need another

\footnotetext{
E-mail address: annatina.aerne@unil.ch.

1 The article focuses on the primary market, because the Colombian secondary art market is still incipient. The first Colombian auction house, BogotáAuction has been established in 2015. It can be assumed that it still serves a predominantly local public.
} 
author, editor or at least a prefacier transferring some of their prestige to the foreign author. A second challenge refers to the fact that local sellers and foreign buyers of contemporary art need to be brought together. Without an encounter of buyers and sellers in virtual or physical space, so-called match-making, a transaction does not happen (Callon, 2016: 30; Karpik, 2010: 46). This, too, is not easy in contemporary art markets where buyers like to see the artwork before buying it. International sales depend on the participation in costly international fairs. Both of these steps, valuation and match-making are not easy for Colombian art organizations. Yet, they have achieved to capture some of the international attention in recent years.

Drawing on the literature of economic sociology, the article develops a typology of brokers undertaking valuation, match-making, none or both of these steps. The article then identifies an empirical example corresponding to each of the ideal types proposed by the typology, drawing on 36 semi-structured expert interviews conducted at three different time points between 2015 and 2016 . The paper highlights the challenges and advantages associated with these different types of brokerage as experienced by Colombian art professionals. The analysis suggests that transactions are most encouraged if the party that determines the value also organizes the buyerseller encounter. Match-makers that are not accepted valuators are perceived to affect the valuation of the good negatively, through their involvement in the transaction. Valuators that do not engage in match-making are helpful in establishing the value of art in Europe and the US, but it is not clear whether or not this results in transactions.

This paper's contribution consists in shedding light on the challenges that keep the contemporary art market from becoming global. It thereby builds a bridge between the macro-perspective looking at the internationalization of the 'global' art field, and the more bottom-up perspective of the political economy of emerging art scenes. Section 2 introduces the internationalizing art field and the political economy of the Colombian art scene. Section 3 discusses the literature on valuation and match-making and develops a typology for intermediaries, based on these two activities. Section 4 presents the data and the methods. Section 5 analyses how the Colombian art scene has internationalized and observes which intermediaries value Colombian art before an international audience and bring buyers and sellers into contact. Section 6 draws conclusions and suggests avenues for further research.

\section{Context}

From a birds-eye-view, a global ${ }^{2}$ field of art is evolving (Buchholz, 2016). Yet not all regions are equally participating in this global art field. From a bottom-up perspective, observing the political economy of art scenes allows identifying the conditions under which domestic art scenes emerge. The present analysis builds a bridge connecting the two perspectives: it analyses what challenges present themselves in connecting the re-emerging Colombian art scene to the global field of art.

\subsection{Globalizing art field}

From a macro-perspective, globalization has led to the emergence of 'global fields' in different aspects of life. Following Bourdieu (Bourdieu, 2014: 17ff), an art field, and hence also a global art field, is defined as functionally (horizontally) autonomous from other fields, such as the economy. A global art field is furthermore vertically independent from national art fields (Buchholz, 2016: 40). The vertical autonomy of a global art field is confirmed by the fact that the local valuation of artists does not always correspond to the international valuation of the same artists.

In the literature on the emergence of global fields, two questions are debated. First, one can ask whether such a 'global' field exists in different realms of life, i.e. if these global fields are sufficiently independent from the domestic fields (Go, 2008; Heilbron, 2014; Luhmann, 1997; Marginson, 2008; Moretti, 2000; Regev, 2008). Second, it is debated if these global fields enable equal participation of all regions. With respect to cultural markets, the picture is mixed. A pattern of centralization characterizes the literary field. 'Western' literary formats, such as the novel, have proliferated all over the world, but non-Western literary formats are consumed predominantly locally (Moretti, 2000: 58). In contrast, the global field of popular culture has become more open and more international, with films and music from different sub-cultures gaining popularity (Regev, 2008: 134).

The extent to which the global contemporary art field is truly global is also debated. In 2018, more than $80 \%$ of the artworks traded for the first or second time changed hands in the US, UK or China (McAndrew, 2018: 34). Europe and the US remain overrepresented, with China catching up. The centralization of the art market is partly driven by the location of major art fairs (Quemin, 2013: 169). Galleries participating in these art fairs are based in these centers, ${ }^{3}$ and tend to represent artists from their home market (Velthuis, 2013: 293). Apart from Japan and China, no artists from non-OECD countries are found among the top ten nationalities represented by foreign galleries (Velthuis, 2013: 294). Artists from Latin America (1\%) and Africa (2\%) are hardly represented at all. Connections across different geographic regions in the contemporary international market remain scarce resulting in a geographically segmented market (Velthuis, 2013: 293; Velthuis \& Curioni, 2015: 17). It is quite difficult for Colombian galleries to reach a significant presence in this international art market. Put differently, a truly global market for contemporary art has yet to be created.

This centralization notwithstanding, the market for contemporary art has slowly diversified geographically since the early $1990 \mathrm{~s}$ (Velthuis \& Curioni, 2015: 2). Growing middle classes and the establishment of art organizations have led to the formation of domestic art scenes, also outside of Europe and the US, and especially in emerging markets. In the last 30 years, the Chinese and Russian contemporary art markets have emerged from non-existence (Kharchenkova, Komarova \& Velthuis, 2015). Both countries have seen

\footnotetext{
${ }^{2}$ We differentiate 'global' from 'international' as follows: global refers to an ideal process involving all regions. 'International' refers to a more realistic, somewhat less encompassing development, where some regions are more concerned by a development than others.

${ }^{3}$ The share of Colombian galleries at international art fairs was 0.05\% (Quemin, 2013: 170).
} 
remarkable growth in the 1990s, and the formation of an elite interested in art. Like the Russian and Chinese economies, India has seen rapid growth in the 1990s, with an emerging elite buying art (Komarova, 2018: 39). In Latin America, particularly Brazil's contemporary art scene has attracted international attention (Brandellero \& Velthuis, 2018). The origin of this art scene can be traced to the 1950s, when the Brazilian economy boomed and European immigrants founded important art institutions, such as the biennale of São Paulo and various museums. Especially the biennale has had an international orientation from its beginning, aiming at connecting Brazil's art scene with Europe and the US respectively (Whitelegg, 2013).

The literature has analyzed the conditions under which domestic art scenes have emerged, particularly highlighting the role of a growing local middle class. It has also highlighted various mechanisms and actors relevant in the internationalization of a growing domestic art scene. On the one hand, actors at the center may encourage internationalization, first and foremost by involving artists from the periphery on an equal basis (Cabrera, 2007; Morin et al., 2000; Mosquera, 2001, 2002; Ramírez, 1992; Velthuis \& Curioni, 2015). In the case of the internationalization of the Indian art scene, major western museums and galleries taking up the discourse built around Indian artists and artworks were important (Khaire \& Wadhwani, 2010: 1294). In addition, central actors' resources may also play an important role, such as when foundations sponsored by the EU invite Turkish artists to present their work (Madra, 2008: 106). On the other hand, local actors from the periphery, such as institutional entrepreneurs may also promote an internationalization of their art scenes (Velthuis \& Curioni, 2015: 11). The participation of local art galleries in international art fairs contributed to an internationalization of the Indian art scene (Sooudi, 2015: 268). Moreover, local policy makers also have an influence, i.e. through tariffs and duties (Velthuis \& Curioni, 2015). In the following, I contribute to this literature in providing a more systematic analysis of intermediaries connecting these emerging art scenes to the center of the artworld, drawing on the Colombian experience.

\subsection{The political economy of the Colombian art scene}

Colombia is not usually among the prominently discussed emerging art scenes, but has received more international attention recently. Originally attributed the role of nation-building, Colombia's art scene has seen a first period of increased activity in the 1950s for and by domestic actors predominantly. It has seen a second remarkable development in the 2000s. In contrast to the earlier flourishment, Colombia's art scene has also received increasing international attention in this recent boom.

In the early nineteenth century, collecting and exhibiting art was of central importance in creating a common basis for a young, still forming nation. The foundation of the national museum right upon Colombia's independence in 1810 shows the relevance attributed to culture in nation building (Ministerio de Cultura, 2010a: 298). The role of art to represent and build a Colombian society is also exemplified by the central bank's cultural involvement. In 1930, it decided to exhibit rather than melt pre-Colombian gold objects (Urrutia, 2013: 53). The central bank's involvement in culture is not limited to art, but extends to libraries and concert halls, not only in Bogotá, but throughout Colombia. Up until the present, it is perhaps Colombia's most important public cultural institution, and certainly with respect to visual art. Such a strong cultural commitment by the central bank - the institution in charge of Colombia's currency - also exemplifies the national significance attributed to culture in these early times. Artworks were thus not understood as an economic good, but as creating and representing a newly founded nation to itself. Accordingly, outside of these renowned, national collections opportunities to commercialize, or even just exhibit art were limited. There were neither museums dedicated to art, nor art galleries. Instead, artists exhibited in private showrooms. The first public forum for artists was the Salón Nacional de Artistas founded in the 1930s. The Salón Nacional is essentially a national competition organized yearly by the Colombian government inviting artists to submit their artworks (Serna, 2009: 64). Its format - a national competition - also reflects the endeavor to build a national artistic community. The role attributed to art to contribute to nation-building has remained important until recently. The 1992 constitution for instance highlighted culture as an important means to recognize minorities, and to integrate a divided society (Gautier, 2001: 377f). The cultural recognition of minorities and the reconciliation and integration of a society divided by civil war was thus of central concern up until the 1990s.

A Colombian art scene first started to emerge in the 1950s (Serna, 2009). The foundation of the first private galleries was due to two developments: first, a coffee bonanza in the 1950s increased wealth among Colombians and allowed them to buy art. This new elite also sought to distinguish itself through cultural consumption and started developing a taste for modern art. Second, the political situation in the country did not allow the government to extend continued and professional support to the cultural scene. The 1950s were marked by a period of extreme bi-partidist violence, starting with a brutal riot in Bogotá in 1948 (Bogotazo). The political turmoil resulted in suspending the organization of the Salón Nacional in these years; or in exhibitions that were not recognized as representative of the scene by the artists. In consequence, artists had to organize themselves in order to make a living. Together, these two developments led to the foundation of the first private gallery in Bogotá, Galerías de Arte S.A. in 1948 (Serna, 2009: 64). The 1950s also saw the foundation of the first museums dedicated exclusively to art with the creation of the Museo de Arte Moderno de Bogotá and the Museo de Arte Moderno La Tertulia in Cali (Ministerio de Cultura, 2010: 300). These institutions - as most of Colombia's art museums are private, not-for-profit organizations, receiving funding from different sources. The timing of this first boom roughly coincides with the art boom in Brazil. However, the Colombian development differs from Brazil, where European migrants founded the first galleries and museums. In Colombia, this first period of activity has been for and by domestic actors, with limited international orientation.

A second period of marked activity started in the early 2000s (Aerne, 2020). The increased activity in Colombia's art scene was proceeded by two developments: Colombia's economic recovery after harsh reforms in the 1990s and a shift in its cultural policy. Starting in 2000, Colombia's middle class expanded (see annex for data). This development followed dire reforms of privatization and liberalization, combined with drug wars in the 1990s. In the 2000s, the country stabilized and its middle class increased (Angulo, Gaviria, \& Morales, 2014: $174 \mathrm{f}$ ). Moreover, a shift in Colombian cultural policy can be observed at around the same time. Since the early 2000s, cultural policy in Colombia has become concerned with 'creative industries.' This marks a departure from earlier 


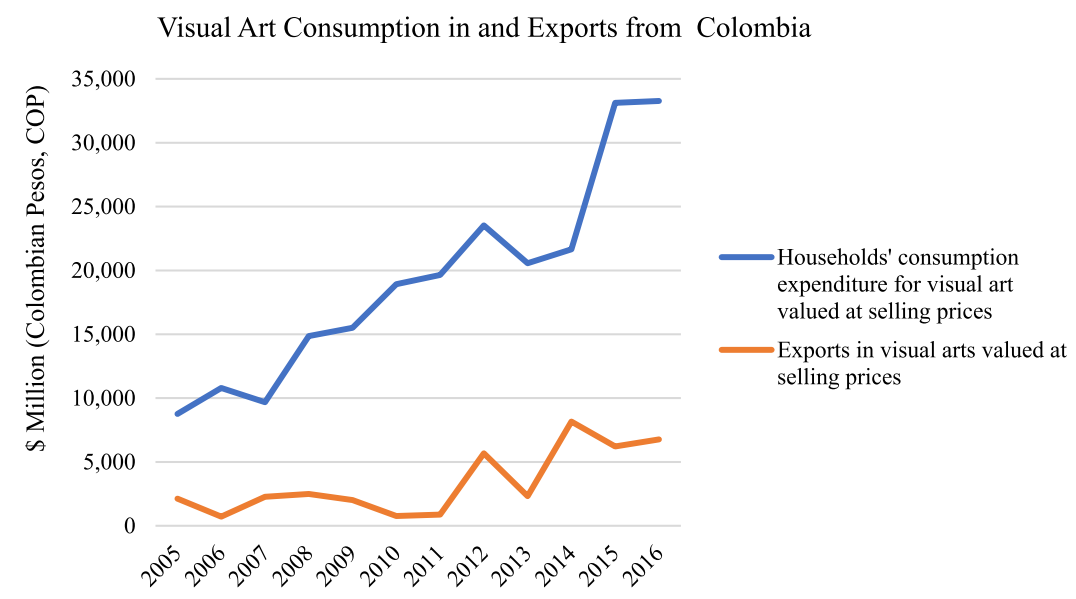

Fig. 1. Visual Arts Consumption and Exports of Visual Arts from Colombia. Source: Departamento Administrativo Nacional de Estadística (DANE), 2018.

inward-looking policies directed at forming a national culture. Culture, and contemporary art in particular, is not conceived any longer as a means to integrate a society torn by civil war, but also to generate economic growth and employment. Art organizations, such as galleries, previously not considered by cultural policies, became important and the object of support measures. In 2003, the Ministry of Culture published a first study on the economic impact of cultural industries in Colombia (Ministerio de Cultura Colombia, 2003). Following this study highlighting the economic importance of the cultural sector, an analysis by the Consejo Nacional de Politica Económica y Social (Conpes) specified how to best support commercial cultural organizations (Conpes. Consejo Nacional de Política Económia y Social 2010). The document identifies five areas of action, where cultural organizations should receive support, such as distribution channels, and access to finance. In May of 2017, Colombia adopted a new law 1834, a so-called Ley Naranja (orange law) as cultural industry is also referred to as 'industria nararanja', which aims to provide ideal conditions for cultural entrepreneurs, such as tax incentives.

On the district level of Bogotá, creative industries are supported by local agencies. Bogotá's Chamber of Commerce caters to clusters of entrepreneurs in cultural industries, and organizes fairs for fashion, music production, and audiovisual production. Most importantly, since 2004 it organizes the country’s largest art fair, artBo. Invest in Bogotá, Bogotá's Investment Promotion Agency, equally promotes the investment into creative production in Bogotá, such as music and film.

The dynamism of Colombia's contemporary art scene eventually also attracted international attention (G5; G3; G2; M4; M5; AF3). This is particularly remarkable, given Colombia's history of inward-looking cultural policy. The international dimension of this boom is reflected in the increasing number of English newspaper articles mentioning 'Colombia' and 'contemporary art' in the factiva database (see annex for data). Comparing the newspaper articles shows an increase since 2000, but no mentions for the first period of activity in the 1950s. This recent 'boom' is also reflected in Colombia's national statistic on cultural consumption and cultural exports shown below. Comparing the entries of the 2014/15 and 2015/16 editions of the booklet Directorio Bogotá Arte Circuito, comprising all art organizations in Bogotá, also shows a marked increase (Peñaranda, Correa, Sánchez, Montejo, \& Guzmán, 2014, Peñaranda, Guerrero, Sánchez, Bray, \& Ferregán, 2015). Moreover, the development was not restricted to commercial galleries. There has also been a 'boom' of independent art spaces at the same time - spaces directed by artists, rather than gallerists (Castellanos, Machicado \& Peláez, 2015: 8).

(Fig. 1)

The recent internationalization of Colombian art raises the question: How did Colombian art organizations reach an international audience to a larger extent in recent years?

\section{Theory: challenges in the creation of an international market for Colombian art}

Economic sociology suggests that transacting involves at least two crucial actions. First, a good's value must be established and accepted both by the seller and the buyer (Beckert, 2009: 253; Beckert \& Aspers, 2011). This turns out to be particularly difficult for artworks, whose value is established in networks, rather than measured objectively by a scale. If these networks do not extend across borders, the value of artworks does not travel abroad. Second, sellers and buyers need to be brought together (Callon, 2016: 30; Karpik, 2010: 46). Again, this turns out to be particularly difficult for contemporary art, because collectors wish to see their potential acquisitions live. This means, costly international travels are necessary in order to internationalize art markets. 


\subsection{Valuation}

Goods valuation ${ }^{4}$ is essential in establishing market transactions (Beckert, 2009: 253; Beckert \& Aspers, 2011). A good is only bought if it provides value to the buyer. Goods' valuation is not as trivial as it may seem at first sight. The establishment of value is particularly difficult in so-called status markets. A status market lacks a scale that is independent of buyers and sellers and establishes the value of a good. In status markets goods are evaluated with reference to actors who supply or demand the good. These buyers and sellers stand in rank order of interrelated status positions, and the value of the good traded reflects its origins and destinations. The value of art is based on its status established in networks of actors, rather than objective measures (Aspers \& Beckert, 2011: 17f; Aspers, 2009; Velthuis, 2013).

Such status markets can be distinguished from standard markets. In status markets, valuation is best described as an intersubjective process (Helgesson \& Muniesa, 2013): value cannot be measured objectively. Nonetheless, people tend to agree on something being more or less valuable. Contemporary art is a classic example for such a status market. In contrast, objective measurement is more easily achieved in standard markets. Standard markets are defined by the existence of a scale of valuation for what is offered in the market that exists independently from the buyers and sellers. Buyers and sellers consult this scale when evaluating goods. An example for such a market would be the gold market. Gold can be weighed and its value is established by an external reference scale.

The difficulty of valuation of artworks has long been recognized in the literature on cultural industries. Intermediary organizations and institutions (e.g. museums and galleries) are needed to distinguish artworks from mere sensory experience and to establish their value. The consensus reached by these gatekeepers on the status of an artwork establishes its worth. Arthur Danto has observed that a 'theory of art' accepted by an 'art world' is needed for works to acquire their status as art. For instance, this world's judgment distinguishes Warhol's Brillo box, which is considered art, from an ordinary Brillo box containing soap (Danto, 1964: 581).

In this artworld, some actors have valuation authority. Their valuations are accepted by other actors, who agree to acquire the goods offered to them (Callon, 2016: 30; Lamont, 2012: 21.6). In practice not any single one of these organizations is powerful enough to establish or break an artist. The convergence of various organizations' judgments ensures the status of artworks and determines their value. Whole networks of organizations, which confirm each other's valuation, are needed to ensure the status and price of objects as artworks (Bourdieu, 1994; Bystryn, 1972; Currid, 2007; Danto, 1964; Styhre, 2013; Zuidervaart, 2011). As the word suggests, these gatekeepers watch the gate-i.e. they guarantee that those artworks that cross the threshold are worthy of doing so.

The value of artworks is thus established and stored in networks. This means that a good's value only travels as far as the network in which it is established, extends. Valuation in status markets is problematic across communities: a good's value may be accepted in a certain community, but not in another (Bessy \& Chauvin, 2013: 93; Bourdieu, 2002). In absence of networks of valuators that extend from Paris and New York to Bogotá, the internationalization of the art market is limited.

Hence, a first challenge in counteracting the centralization described ealier is to have the value of Latin American art accepted by international collectors. This is difficult if gatekeepers at the center do not value Colombian art, and collectors rely on these intermediaries' valuation. Networks connecting local gatekeepers in Bogotá with those determining the selection in the center become essential: intermediaries accepted both, in the EU and US as well as in Colombia are needed in order to establish the worth of the good in these communities. Only when the networks in which an artwork's value is established extend abroad, transactions across borders become possible.

\subsection{Matchmaking}

A second challenge in transacting art from Colombia internationally is the bringing together of buyers and sellers. Market transactions involve sellers and buyers, which need to meet in a physical space (Callon, 2016: 30; Karpik, 2010: 46). In Callon's framework of market agencement ${ }^{5}$ (agencement marchand), connecting buyers and sellers is described as orchestration (Callon, 2013: 346). Karpik describes as confluences 'the many techniques used to channel buyers, whether in shopping malls or luxury shops, and range from territorial location, spatial organization, and displays to sales skills (Karpik, 2010: 46).

In the internationalization of an art market, the difficulty of arranging a meeting between buyer and seller is evident. Selling art abroad requires presenting it abroad or international visitors travelling to see the work. Although many collectors are wealthy enough to travel, even to far-away destinations, they usually buy from nearby galleries (SteinerLasse, Bruno, \& Resch, 2013). In contrast, local art organizations often find attending fairs or travelling abroad too expensive, which prevents galleries from being present at international art fairs or artists from exhibiting at international shows.

Today's communication technologies facilitate new ways of organizing market encounters virtually (Callon, 2013: 367). Although these technologies also play a part in art markets, artworks are still largely traded only after visual inspection, which requires physical

\footnotetext{
${ }^{4}$ Valorizing (attributing value to something), can be distinguished from evaluating (estimating the value of something). In practice these two processes can hardly be separated (Vatin, 2013). Valuation in the following therefore refers to the act that establishes and thereby attributes a certain value to a certain good.

${ }^{5}$ Following Callon, the establishment, maintenance and proliferation of market transactions is not a process that takes place automatically. Rather, it needs actors to engage in 'market agencement' (Callon 2016: 28). In particular, actors need to undertake five steps (Callon 2013: 346): (1) good passivation, which enables transfer; (2) the existence of calculating agencies, which determine the value of a good; (3) organizing buyer-good encounter (orchestration); (4) the buyer's emotional attachment, to ensure she or he is prepared to pay a price for the good; (5) and price formulation. In this paper, we draw on the third step of Callon's framework, namely orchestration.
} 
Table 1

Typology of Market Intermediaries. Source. Own Data.

\begin{tabular}{lll}
\hline & Valuation & No valuation \\
\hline Match-making & Type 2 & Type 3 \\
No match-making & Type 1 & 0 \\
\hline
\end{tabular}

Table 2

Research Steps. Source: Own Data.

\begin{tabular}{|c|c|c|}
\hline February 2015 & October 2015 & October 2016 \\
\hline $\begin{array}{l}\text { Interviews } \\
\quad \text { Round } 1\end{array}$ & $\begin{array}{l}\text { Interviews } \\
\text { Round } 2\end{array}$ & Interviews Round 3 \\
\hline Large galleries & Museums & $\begin{array}{l}\text { Smaller organizations (independent art spaces and galleries), public authorities, and some of the organizations that } \\
\text { were interviewed in February of } 2015 \text {. }\end{array}$ \\
\hline (6 interviews) & (12 interviews) & (18 interviews) \\
\hline
\end{tabular}

work-buyer encounters. Art transactions remain dependent on face-to-face buyer-seller meetings — at fairs, in gallery showrooms or in artist studios - even if information about works is readily available online. In 2016, art dealers ${ }^{6}$ completed $51 \%$ of their sales ${ }^{7}$ in their showrooms, while art fairs accounted for 41\% and online sales for the remaining 8\% (McAndrew, 2017: 52). Selling a Colombian artwork internationally thus requires travel. It is expensive for Colombian art organizations to attend fairs abroad. Shipping costs, insurance, flights, and the fees for attending fairs challenge the budget constraints of Colombian galleries. This financial hurdle is exacerbated by Colombian galleries facing price differences between Colombia and the US or Europe, which also affect the pricing of art, and hence potential revenue.

Among others, these two difficulties, the valuation of Colombian art, and the coordination of encounters of buyers from Europe and the US and local sellers thus impede the internationalization of the art market. The creation of an international art market for Colombian art needs actors that perform two actions: valuation and match-making. Valuators and match-makers may or may not coincide. Valuation needs to be performed by actors that are accepted valuation authorities in the international artworld. Matchmaking can only be performed by intermediaries that have the resources to finance international travel. This leaves four possible ideal types of market actors, that contribute to an internationalization of the art market: valuators who assess the goods (type1), some that do both (type 2) and match-makers that put into contact buyers and sellers (type 3). Intermediaries that do not perform either of the activities are left out from the analysis, since their contribution to establishing an international market is assumed to be marginal (0).

(Table 1.)

\section{Data and methods}

The paper relies on 36 semi-structured expert interviews with art organization directors in Bogotá. All interviewees were asked to describe their efforts to reach international buyers or museum visitors. They described different forms of brokerage and the benefits and challenges associated with them. Interviews were conducted on-site in Spanish and then transcribed. Next, brief summaries were written, comparing the strategies of organizations to reach an international public to the ideal types of brokerage developed in the theoretical framework. Matching these data with the typology just developed allowed obtaining new insight into how Colombian art organizations managed to reach an international audience, to a larger extent in recent years.

The art organizations were sampled so as to get a representative picture of Bogotá's art scene, and their strategies to internationalize. The first round of interviews (February 2015) involved the most recognized galleries. 'Recognized' here refers to those galleries in Bogotá invited to ARCO Colombia, the special section of Madrid's International Art Fair, in February 2015. Every year, ARCO invites a special guest country, and in 2015 this was Colombia. The second round of interviews (October 2015) involved all of Bogotá's major museums with at least a partial focus on contemporary art: Museo de Arte Contemporáneo, Museo de Arte Moderno, Museo Nacional and Museo del Banco de la República. Interviews also included an independent art space, which was also invited to ARCO and the organizers of artBo.

The third round of interviews (October and November 2016) included smaller organizations. These organizations were selected based on two criteria. Since they had filled in a survey for another study, they were assumed to have the personnel capacity and willingness to respond to an interview request. At the same time, these organizations had never participated in artBo, and thus were not among the most established galleries. During the third round of interviews public authorities responsible for art and cultural policies were also interviewed. Some of the established galleries were interviewed a second time during this third round of interviews. These

\footnotetext{
${ }^{6}$ Data on sales from dealers are difficult to obtain. This study cites data collected from 5,400 dealers in the US, Europe, Asia, Australia, Africa, and Latin America, either directly or through the major dealers' associations. The survey had a response rate of $17 \%$.

7 Although it would have been desirable to obtain more recent figures, the new editions of the Art Market Report do not feature such detailed information on galleries' sales channels.
} 
selected galleries had refrained from participating in the local art fair artBo due to financial difficulties and were assumed to have experienced notable changes.

(Table 2.)

\section{Case: Empirical examples for the three types of brokers}

Which brokers established the value of Colombian art to international buyers, and which actors financed the encounter of buyers and sellers? The following reviews the contribution of different types of brokers in this process of internationalization and categorizes them according to the typology just presented.

\subsection{Broker type 1: Return of lost daughters and sons}

Without an internationalization of the network of actors that valuate Colombian art, international transactions of Colombian art remain highly unlikely. In Colombia, such intermediaries include a handful of Colombian art professionals who have been successful outside their home country and have recently returned to Bogotá. These art professionals founded their own galleries and independent art spaces, upon their return. Their valuation authority has been established in international art centers and their return to Colombia signals the value of local artistic developments. The importance of such internationally recognized figures has also played a role in the emergence of the art market elsewhere in Latin America, for instance in Brazil (Brandellero, 2015).

These art professionals best correspond to a type 1 intermediary: they value Colombian art, but do not match the buyers and sellers. Regarding valuation, it can be observed that these art professionals attract the attention of their former colleagues to the Colombian art scene and signal the value of local artistic production to their former colleagues, beyond their own organizations. Museum directors, curators, and gallerists from Europe and the US follow the new projects of their friends in Bogotá and come to look at the art scene more broadly. As their art organizations are among the few that are financially able to commercialize artists internationally, they are also involved in match-making. These examples hence do not correspond perfectly to the typology. However, they do not engage in matchmaking for Colombia's art scene more generally, but only for their own organization. Thus, they do signal the value of Colombian art, but don't arrange a meeting of buyer and seller beyond their specific selection of artists. They are therefore seen as an example of type 1 brokerage. $^{8}$

One very prominent figure in this respect is José Roca, a former curator of London's Tate Modern. As an established authority, he confirms the value of Colombian art toward an international audience (G7). In 2013, Roca founded the independent art space Ars+Flora in San Felipe, one of the residential areas in Bogotá where many new galleries opened between 2011 and 2016. His-selection serves international collectors as a reference point for 'high quality' Colombian art. His authority, confirmed by the Tate Gallery (London), means that his selection also establishes the value of Colombian artworks internationally. Moreover, Ars + Flora relies on extensive international connections. The foundation maintains different contracts with foreign state institutions, which send their artists to Ars +Flora for residencies and cover their expenses (F3). This scheme allows artists from Mexico, Chile and Brazil to spend several months in Colombia and to present their work in Bogotá. These connections also lead to this foundation being accepted as an equal on the international level.

José Roca is not the only internationally recognized art professional to have returned to Colombia. Two other highly successful and internationally experienced gallerists have recently returned to Bogotá and now direct two highly reputed local galleries. Catalina Casas, who founded an acclaimed gallery in Miami returned to Bogotá in 2005 to establish Casas Riegner. Given her success in the US, international collectors trust her selection of artists and artworks to comply with international 'quality standards.' This recognition allows Casas to establish the value of Colombian artworks internationally. The international acceptance of her gallery is also cemented by its presence at major international art fairs, such as Art Basel Miami Beach. Similarly, Beatriz López, the former director of art spaces in London and Mexico, returned to Bogotá in 2015 and opened the Instituto de Visión with two associates (G2; G6; F3). Again, the value of the presented artworks is accepted as equal to galleries in London and Mexico. Instituto de Visión has also been present at various international art fairs, having its selection valued on the international stage.

An important feature of these type 1 brokers is that they also connect the local art scene to international art collector epistemically. Along with other gallerists and institutions, Catalina Casas and Beatriz López managed to establish a discourse referring to Colombian artists as pioneers, referents and visionaries (Aerne, 2018). This discourse on pioneers, referents and visionaries highlights the artists' significance before an international public unfamiliar with Colombian art history. Visionaries, pioneers and referents are hence terms

\footnotetext{
${ }^{8}$ Assumingly, these Colombian art professionals also attracted the attention of their European and American colleagues with their projects when they were still in London and Miami. However, it remains unclear to what extent this attention also benefited Colombian artists beyond the ones represented by these art professionals in the center. One might assume that their presence in Bogotá signals the relevance of the developments in Bogotá's local art scene, whereas their presence abroad signals the opposite. Foreign art professionals previously successful in the center and then active in Colombia assumingly would equally value Colombian art. This points us to an important insight: a valuator needs to be accepted by a public abroad, as well as being established locally.

${ }^{9}$ The categories were defined as follows (Angulo, Gaviria, \& Morales, 2014: 175): (1) Poor: households with an income per capita below the poverty line (USD \$4.06 PPP), (2) Vulnerable: households with an income per capita between the poverty line and USD \$10 PPP, (3) Middle Class: households with an income per capita between USD \$10 and USD \$50 PPP, (4) Upper Class: households with an income per capita larger than USD \$50 PPP.
} 
that attribute value to these artists. The importance of creating such epistemic connections has also been observed for Indian modern art (Khaire \& Wadhwani, 2010).

\subsection{Broker type 2: artbo}

In addition to these internationally recognized Colombian art experts, the country's major art fair (artBo) has managed to become an internationally accepted arbiter on (and hence guarantor of) the value of local art. Apart from signaling the value of Colombian art to foreign art collectors, artBo also engages in match-making. It invites VIP from Europe and the US to visit Colombia and the fair. It therefore serves as an example for type 2 brokerage.

The fair has established itself as a valuator also accepted on the international level, through different mechanisms. The fair only admits a limited number of local galleries, which signals exclusivity to international buyers. artBo emphasizes that it has not expanded over the last few years, even if the size of its venue would easily make this possible. Instead, it has remained selective, meaning that the fair is appraised to offer better curated content every year (RO1). Moreover, artBo attracts galleries from abroad (G4), which further affirms its international standing as the admitted Colombian galleries are evaluated against international competition. Supporting the discourse of leading galleries, artBo also hosts a special section for artists termed 'referentes', in order to establish clearly identified categories for Colombian art. artBo also enjoys acclaim because it is seen as 'neutral,' due to its funding by Bogotá's Chamber of Commerce (F1). Previous attempts to establish a Colombian art fair were initiated by local galleries, whose selection was perceived as biased by their competitors. artBo's impartiality might also contribute to its standing and acceptance among both the participating galleries and its international audience.

The fair not only values Colombian art, but also attracts international buyers (G3; G4; G14; G1; G13; F1). artBo even invites international collectors, and thus effectively brings an international public in contact with Colombian artworks. In fact, international buyers have become an important audience for the fair (AF1), as one of the organizers expressed:

'The international program is very important because it also supports the sales at the fair, and it remains necessary to bring in these international people for the fair to be successful in terms of sales. Only Colombian collectors would not allow for the number of galleries that the fair admits.'

artBo organizes special VIP programs, where international visitors are shown not only the art fair, but also guided through private and institutional collections. As such, the fair plays a key role in matchmaking, i.e. the sales of Colombian art to an international audience.

\subsection{Broker type 3: Cultural division of Colombia's ministry of external relations}

A third type of intermediary is the Cultural Division of Colombia's Ministry of External Relations. Colombia's Ministry of External Relations has been active as a match-maker, supporting the shift of cultural policy towards commercialization of Colombian art described earlier, also internationally. However, the extent to which the Colombian Ministry of External Relations is an accepted art valuator, is debatable. In contrast to the other two types of brokers, it is not firmly rooted in the local art scene. As will be discussed below, this type of intermediary would thus perhaps best exemplify a type 3 intermediary: a match-maker that is however not perceived to value Colombian art before an international audience.

Colombia's Ministry of External Relations has started to engage as a match-maker in its endeavor to support carry out the shift in cultural policy towards 'cultural industries' described in the context section. It increasingly promoted the internationalization efforts of profit-oriented art organizations in recent years (G7; G14). Cultural diplomacy was strengthened in 2000, with contemporary art occupying a more important role (Ruiz, 2017: 166). While cross-border cultural promotion was also pursued under previous administrations, this one took a more systematic approach. It devised conceptual guidelines, as part of a comprehensive cultural plan, the so-called Plan de Promoción de Colombia en el Exterior. Under this initiative, the country's embassies and missions were requested to indicate which cultural events they were planning. Notably, the plan referred to the visual arts as 'creative industries,' aligning with the shift in cultural policy. The information provided by the embassies allowed the government to better coordinate cultural activities, and thus to convey a positive image of Colombia.

This systematic inclusion of visual art in foreign policy, and the collaboration between the ministries of external relations and culture, was maintained by later administrations (2010-2018) (Ruiz, 2017: 197). The Head of Cultural Affairs at the Ministry of External Relations, explained that their cultural activities focused on promoting contemporary art, in particular between 2011 and 2016 (PA1). In fact, the Head of Cultural Affairs at the Ministry of External Relations argued that visual art was particularly well suited to create positive associations with Colombia:

'I believe that there is a great intellectual force, and that the development of the visual arts in Colombia is a development, or is one of the more sophisticated artistic expressions in terms of thought, elaboration, and global contact.'

One very prominent project supported by the Ministry of External Relations was Colombia's invitation to ARCO, the international art fair held in Madrid in 2015. Curator Juan Andrés Gaitán selected ten Colombian galleries and from each two of 'their' artists. The participation fee was waived while various Colombian public authorities sponsored the selected galleries' travel and accommodation expenses. The ARCO invitation provided the selected galleries with an outstanding opportunity to present themselves on an 
international stage, which would have otherwise been impossible for monetary reasons.

However, the Colombian Ministry of External Relations' selection for ARCO was not accepted in the Colombian art scene, but instead perceived as serving political purposes and thus as being based on criteria other than 'value.' Some gallerists observed a selection bias in terms of medium and topic: The curator seemed to prefer media other than drawing, for which Colombian art is well known, and topics other than violence (G5). ARCO was seen as an artistic platform serving to demonstrate that Colombia had more to offer besides narco-trafficking and its effects on Colombia (RO1). The political purpose of presenting art abroad also became evident when the then President Santos paid a state visit to Spain and also attended ARCO. The visit aimed to promote the peace agreement with the Fuerzas Armadas Revolucionarias de Colombia (FARC) underway at the time. The fact that governmental authorities used a major international art fair as a political platform was not very well received by the galleries.

Being aware of the fact that the selection may not coincide with their own valuation of artists, galleries devised different strategies to bypass or mitigate the official section. Thus, in addition to their government-sponsored booth, larger galleries (e.g. Casas Riegner) presented their own selection at the fair, passing through the fair's normal selection process and paying the fee for a regular booth. In being admitted through the regular criteria, Casas Riegner established the value of their selection before an international public. Other galleries (e.g. Valenzuela Klenner) had a clandestine presence in the hallway, where they showed artists that were not selected, working exclusively on narco-trafficking. Some gallerists were initially enthusiastic about this possibility, but changed their minds (G3). A year after the fair, one of these gallerists felt that ARCO had merely served as a stage for national politicians to cast Colombia in a positive light (G3b):

'We are all marionettes of many things. We try not to be, but at the end of the exercise, if we are relevant and if we have a national connotation, they like to show us off as something positive of the country.'

The Cultural Division of the Ministry of External Relations denied any thematic restriction (PA1) and pointed out that the accompanying exhibitions featured depictions of Colombia's violence. This official account relativizes the gallerists' impression that certain topics had been censored at ARCO. Nevertheless, their perception points to the delicate balance between receiving financial support to bring cultural production to consumers, and to value it.

The brokerage of Colombia's cultural division of the Ministry of External Relations highlights thus the difficulty of having a matchmaker, that is not firmly rooted in the local art scene. The Ministry of External Relations employed an independent curator in order to select the galleries and artworks, but even so, it was perceived to be involved in the selection. A selection influenced by an entity without the appropriate authority was seen as invalid by the Colombian art scene. Being selected by a match-maker not firmly rooted in the art scene may taint the artworks' valuation, because it is interpreted as the artwork's inability to pass the stricter selection by a more recognized valuator. In the example of ARCO Madrid, galleries mitigated the stigma of accessing this prestigious fair through a special and less recognized pathway, by going through the regular submission procedure and paying the hefty fee. Presenting 'their' selection separately from the official section whenever possible, they avoided the Ministry of External Relations involvement in the match-making.

\subsection{Comparison of types of intermediaries: valuation and/or match-making}

Three different types of intermediaries have contributed to internationalizing the Colombian art scene. First, the value of Colombian art is established by internationally reputed Colombian art professionals, who have returned to Colombia and act as trusted valuators also for an international audience (type 1). Second, Colombia's art fair (artBo) selects Colombian galleries against international competitors and hence establishes their value in the international scene (type 2). Moreover, artBo invites international visitors to the fair, thereby facilitating potential transactions. Third, the Ministry of External Relations has acted as a match-maker and increased the number of encounters between buyers and sellers (type 3).

The three types of intermediaries each are characterized by advantages and face challenges in establishing an international market for Colombian art. It turns out that type 2 intermediaries, combining valuation and match-making are most helpful in building an art market. Type 1 intermediaries, valuing art but not engaged in matchmaking also support the creation of international connections, which however do not necessarily result in market transactions. Type 3 intermediaries organize transactions, without being accepted valuators and may have a negative effect on building an international art market. The case of the Ministry of External Relations shows the risk of a match-maker not being an accepted valuator. For the value of an artist or artwork to cross borders it is thus best, if matchmaking and valuation is done by the same intermediary. This differs from brokerage in other trades. In financial industries, i.e. maximal independence between match-makers and evaluators is needed in order to establish the value of goods (Leyens, 2011).

The examples of different types of intermediaries provided lend themselves to generalization along the activities they perform: valuation and match-making. This makes the typology applicable across different cultural contexts, as specific formats of art fairs, or galleries may not be equally prevalent everywhere. Yet at the same time, this makes a generalization based on the intermediary's organization type difficult. It would be hard to substantiate that art fairs are the best form of intermediation regardless of context, simply because artBo was a successful example. artBo's success is based in its recognition as a valuator of local art in the international 
art scene and its access to resources for match-making. Access to resources as well as recognition as a valuator are not necessarily dependent on a certain organizational form. However, particularly recognition in artistic networks may also be influenced by the type of organization. It is probably not a coincidence that artBo, an art fair, is an internationally accepted valuator, whereas the Salón Nacional de Artistas, a typically Colombian format, is not.

\section{Conclusion}

The present analysis builds a bridge between the literature on the political economy of emerging art scenes, and the scholarship on 'global fields.' In particular, it presents a typology to categorize different types of actors involved in the internationalization of an art scene, based on the task they perform: valuation and match-making. The attribution of value to local art, which is accepted by international collectors proves to be particularly difficult. Artworks' value is established in networks of credited intermediaries. If these networks do not extend globally, artworks' value does not travel across borders. Moreover, for a transaction of contemporary art to take place across borders, it is necessary to arrange a meeting between local sellers and international buyers. This is very costly for art organizations from the periphery. Drawing on the Colombian experience, the article assesses the challenges and advantages associated with each type of intermediary.

The article shows that the creation of an international contemporary art market works best, if the same intermediary performs both actions, valuation and match-making. Artworks are goods whose worth depends chiefly on the prestige of the entities dealing with it and are particularly vulnerable to contacts with entities that are not accepted evaluators. A matchmaker that does not have the required status and is considered to select artworks devalues them. Credible valuators need to be firmly rooted in the artistic scene locally, and also be internationally accepted. Unfortunately, such actors of the art world situated in peripheral regions rarely have the resources to invite international guests or to send artists abroad. Consequently, certain art scenes are prevented from connecting with major centers. Similar dynamics can be assumed to characterize other art scenes, and the findings are thus relevant not only for Colombia. The typology developed is generalizable to other regions as valuation and match-making are key to internationalizing contemporary art regardless of its cultural context. Successful intermediaries need to be both, accepted valuators in the international art scene, and equipped with the necessary resources to engage in match-making. Both, international recognition as well as access to resources assumingly depend on various factors, including the intermediary's type of organization. Further research would be needed to analyze the extent to which the internationalization of an art scene also promotes isomorphism among art organizations (DiMaggio \& Powell, 1983).

The findings may also generalize to other types of status markets. In status markets, value is established in reference to buyers and sellers (Aspers, 2009; Aspers \& Beckert, 2011). Involving intermediaries without the required standing tends thus to be more problematic in these markets. The findings in this paper may extend to the establishment of global fields in general where the value of products traded is not easily determined by reference to an external scale, such as wine, jewelry, fashion or other luxury products. Further research is needed to more closely examine the markets in which a division between matchmaking and valuation is perceived as problematic.

\section{Acknowledgements}

I thank four anonymous reviewers for their very helpful comments that greatly improved the paper. I also thank Marianne Jäggi Aerne, Peter Aerne, Lea Bühler, Ana Esquinas and Hugo Marcos-Marné for their critical and constructive feedback.

\section{Annex: List of Interviewees}

Galleries that were invited to ARCO Madrid in 2015, and one additional gallery that was in the process of establishing itself (El Dorado)

1 Casas Riegner: Director, October 5, 2015: G1

2 Casas Riegner: Gallery Assistant, February 4, 2015: G2

3 Doce Cero Cero: Director, February 9, 2015: G3

4 LA Galería: Director, February 5, 2015: G4

5 Nueveochenta: Director, February 3, 2015: G5

6 Instituto de Visión: Director, February 17, 2015: G6

7 Valenzuela Klenner: Director, February 10, 2015: G7

8 El Dorado: Director, October 17, 2015: G8

Interviewed a Second Time

1 Doce Cero Cero: Director, November 2, 2016: G3b 
2 LA Galería: Director, November 18, 2016: G4b

3 El Dorado: Director, November 24, 2016: G8b

Smaller Galleries

1 La Escalera: Director, October 24, 2016: G9

2 Paola Pérez Galería: Director, November 4, 2016: G10

3 Neebex: Director, November 6, 2016: G11

4 Neebex: Curator, November 6, 2016: G12

5 Galería Otros 360: Director, November 16, 2016: G13

6 Nest Art Center: Director, October 25, 2016: G14

Art Fairs

1 artBo: Program and Content Coordinator, October 16, 2015: AF1

2 artBo: Coordinator of Artecámara, October 16, 2015: AF2

3 Odeón: Coordinator Feria Odeón, November 3, 2016: AF3

Independent Art Spaces

1 KB Espacio: Director, November 2, 2016: IAS 1

Museums

1 Museo de Arte Moderno de Bogotá: Curator, October 13, 2015: M1

2 Museo de Arte Moderno de Bogotá: Director, directed the museum from 1969 - 2016, October 20, 2015: M2

3 Banco de la República: Member of the Committee of Acquisitions, October 6, 2015: M3

4 Banco de la República: Director of the Subgerencia de Arte del Banco de la República, October 20, 2015: M4

5 Banco de la República: Curator, October 20, 2015: M5

6 Museo Nacional: Director, October 21, 2015: M6

7 Museo de Arte ContemporáneoBogotá (MAC): Director, October 7, 2015: M7

Foundations

1 Fundación Arteria: Director, October 25, 2016: F1

2 A Seis Manos: Director, November 23, 2016: F2

3 Ars+Flora: Director, October 9, 2015: F3

Art Market Research Organizations

1 Lado B: Researcher, November 25, 2016: RO1

Public Institutions

1 Ministry of External Relations, Cultural Direction: Director, November 18, 2016: PA1

2 Ministry of External Relations, Cultural Direction: Assistant, November 18, 2016: PA2

3 Embajada Colombiana in Switzerland: Head of the Division Culture, October 12, 2016: PA3

4 Instituto Distrital de las Artes (Idartes): Coordinator Convocatorias, previously in Artes Plásticas, November 16, 2016: PA4

International Perception of Colombia's Contemporary Art Scene

(Fig. 2) 
Document count: Number of articles in factiva database including 'contemporary art' and the country name.

English outlets only, from 1950 - 2020

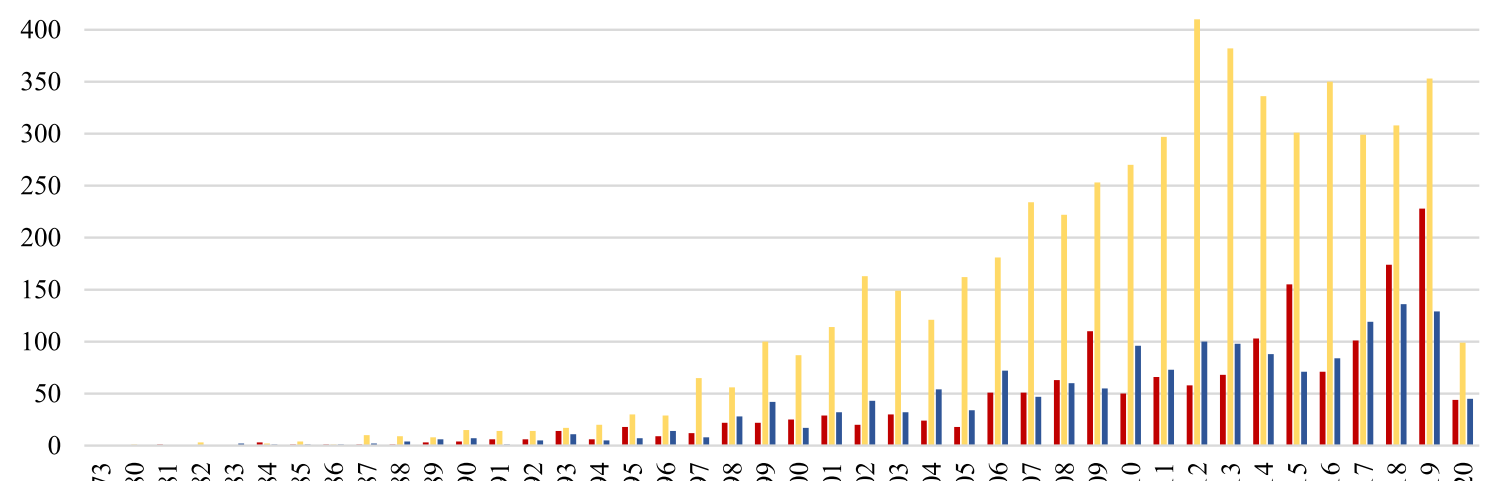

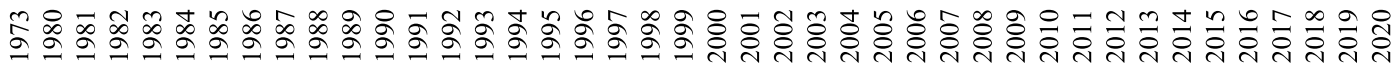

- Document Count for Colombia Brazilian counts घPeruvian counts

Fig. 2. Count of the articles mentioning "Contemporary art" AND "Colombia", "Brazil", "Peru" in the period from 1950 - 2020. Source: factiva database.

\section{Growth of Colombia's Middle Class}

(Fig. 3)

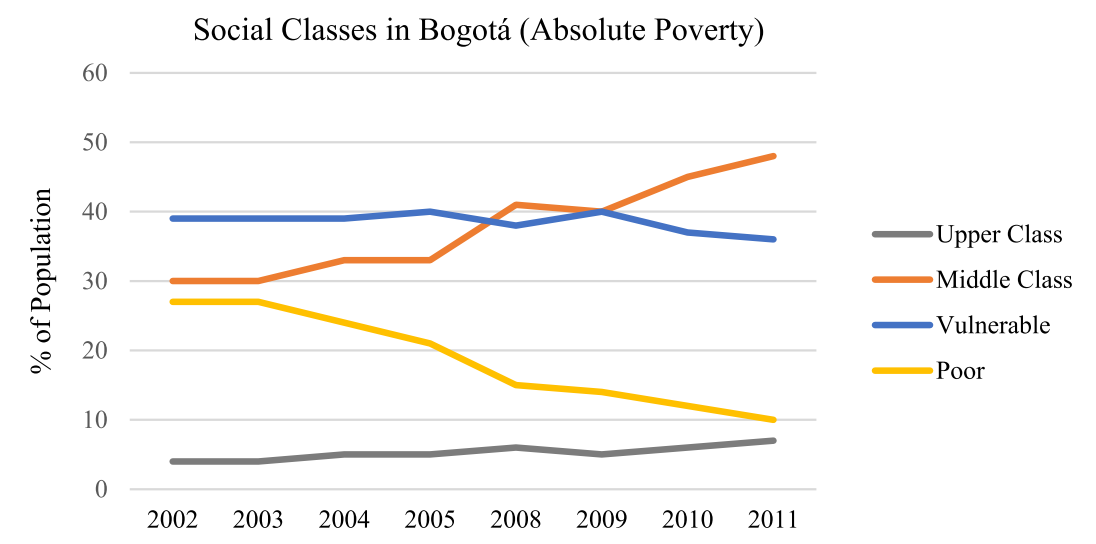

Fig. 3. Emergence of a Middle Class in Bogotá. ${ }^{9}$ Source: Angulo, Gaviria, \& Morales, 2014, p. 200. 


\section{Reference}

Aerne, Annatina (2018). 'El comienzo de una nueva era a partir del reciclaje de los pioneros, visionarios y referentes colombianos'. Mitologías hoy, 17, 65-83. Ministerio de Cultura de Colombia. (2003). "Impacto económico de las industrias culturales en Colombia". Ministerio de Cultura de Colombia, Equipo Central de Economía y Cultura del Convenio Andrés Bello. Bogotá: Convenio Andrés Bello.

Angulo, Roberto, Gaviria, Alejandro, \& Morales, Liliana (2014). "La década ganada: Evolución de la clase media, la pobreza y la vulnerabilidad en Colombia 2002 2011". Coyuntura Económica: Investigación Económica y Social, XLIV, 173-209.

Aspers, Patrik (2009). 'Knowledge and valuation in markets'. Theory and Society, 38, 111-131.

Aspers, Patrik, \& Beckert, Jens (2011). 'Value in Markets.'. In Patrik Aspers, \& Jens Beckert (Eds.), The worth of goods. valuation and pricing in the economy. Oxford. Beckert, Jens (2009). 'The social order of markets'. Theory and Society, 38, 245-269.

Beckert, Jens, \& Aspers, Patrik (2011). 'Value in Markets.'. In Jens Beckert, \& Patrik Aspers (Eds.), The worth of goods. valuation \& pricing in the economy. Oxford: Oxford University Press.

Bessy, Christian, \& Chauvin, Pierre-Marie (2013). 'The Power of Market Intermediaries: From Information to Valuation Processes'. Valuation Studies, 1.

Bourdieu, Pierre (1991). 'Epilogue: On the Possibility of a Field of World Sociology.'. In Pierre Bourdieu, \& James S. Coleman (Eds.), Social theory for a changing society. Boulder: Westview Press.

Bourdieu, Pierre (1994). 'The Field of Cultural Production, or: The Economic World Reversed.' . In Randal Johnson (Ed.), The field of cultural production. New York: Columbia University Press.

Bourdieu, Pierre (2002). 'Les conditions sociales de la circulation internationale des idées'. Actes de la recherche en sciences sociales, 145, 3-8.

Bourdieu, Pierre (2014). Kunst und Kultur. Zur Ökonomie symbolischer güter. Berlin: Suhrkamp.

Brandellero, Amanda (2015). "The Emergence of a Market for Art in Brazil.". In Olav Velthuis, \& Stefano Baia Curioni (Eds.), Cosmopolitan canvases: The globalization of markets for contemporary art. Oxford: Oxford University Press.

Brandellero, Amanda, \& Velthuis, Olav (2018). 'Reviewing art from the periphery. A comparative analysis of reviews of Brazilian art exhibitions in the press'. Poetics, $71,55-70$.

Buchholz, Larissa (2016). 'What is a global field? theorizing fields beyond the nation-state'. The Sociological Review Monographs, 64, 31-60.

Bystryn, Marcia (1972). 'Art Galleries as gatekeepers: The case of the abstract expressionists'. American Journal of Sociology, 77, 639-659.

Cabrera, Marta (2007). 'Representing violence in Colombia: Visual arts, memory and counter-memory'. Brújula, 6, 37-56.

Callon, Michel (2013). 'Qu'est-ce qu'est un agencement marchand?'. In Michel Callon (Ed.), Sociologie des agencements marchands. Textes choisis. Paris: Presses des Mines. Collecion Sciences sociales.

Callon, Michel (2016). 'Revisiting marketization: From interface-markets to market-agencements'. Consumption Markets \& Culture, 19 , $17-37$.

Castellanos, Juliana Barrero, Machicado, Javier Andrés, Peláez, Juan, \& Ministerio de Cultura. (2015). "Caracterización de los espacios de circulación de artes visuales dirigidos por artistas en colombia.". Bogotá: Ministerio de Cultura. Bogotá: Ministerio de Cultura.

Conpes. Consejo Nacional de Política Económia y Social, Ministerio de Cultura. (2010a). Política Nacional Para la Promoción de las Industrias Culturales en Colombia. Industria y turismo ministerio de comercio and departamento nacional de planeación - DDE - dds. Bogotá: Ministerio de Cultura.

Currid, Elizabeth (2007). 'The economics of a good party: Social mechanics and the legitimization of art/culture'. Journal of Economics and Finance, 31, 386-394.

Danto, Arthur (1964). 'The Artworld'. The Journal of Philosophy, 61, 571-584.

DiMaggio, Paul J., \& Powell, Walter J. (1983). 'The iron cage revisited: institutional isomorphism and collective rationality in organizational fields'. American Sociological Review, 48, 147-160.

Gautier, Ana María Ochoa (2001). 'Listening to the state: Culture, power, and cultural policy in Colombia.'. In Toby Miller (Ed.), A companion to cultural studies. New Jersey: Blackwell.

Go, Julian (2008). 'Global fields and imperial forms: Field theory and the British and American Empires'. Sociological Theory, 26, 201-229.

Heilbron, Johan (2014). 'The social sciences as an emerging global field'. Current Sociology, 62, 685-703.

Helgesson, Claes-Fredrik, \& Muniesa, Fabian (2013). "For what it's worth: An introduction to valuation studies". Valuation Studies, 1, 1-10.

Karpik, Lucien (2010). Valuing the unique. The economics of singularities. Princeton: Princeton University Press.

Khaire, Mukti, \& Daniel Wadhwani, R. (2010). 'Changing landscapes: The construction of meaning and value in new market category - modern Indian art'. The Academy of Management Journal, 53, 1281-1304.

Kharchenkova, Svetalana, Komarova, Nataliya, \& Velthuis, Olav (2015). "Official art organizations in the emerging markets of China and Russia.”. In Olav Velthuis, \& Stefano Baia Curioni (Eds.), cosmopolitan canvases: The globalization of markets for contemporary art. Oxford: Oxford University Press.

Komarova, Nataliya (2018). 'Between the market and noncommercial art institutions: Early career strategies of contemporary artists in emerging art scenes'. Poetics, $71,33-42$.

Lamont, Michèle (2012). 'Toward a comparative sociology of valuation and evaluation'. Annual REview of Sociology, 38(21), 1-21.

Leyens, Patrick C. (2011). 'Intermediary independence: Auditors, financial analysists and rating agencies'. Journal of Corporate Law Studies, 11 , 33-66.

Luhmann, Niklas (1997). 'Globalization or world society: How to conceive of modern society?'. International Review of Sociology, 7, 67-79.

Madra, Beral (2008). 'The hot spot of global art'. Third Text, 22, 105-112.

Marginson, Simon (2008). 'Global field and global imagining: Bourdieu and worldwide higher education'. British Journal of Sociology of Education, 29, 303-315.

McAndrew, Clare (2017). The art market 2017. In an Art Basel \& UBS report. Basel: Art Basel \& UBS.

McAndrew, Clare (2018). The art market 2018. In an Art Basel \& UBS report. Basel: Art Basel \& UBS.

Ministerio de Cultura. (2010b). Compendio de políticas culturales. Bogotá: Ministerio de Cultura.

Moretti, Franco (2000). 'Conjectures on World Literature'. New Left Review, 1, 54-68.

Morin, France, Poshyananada, Apinan, Ramírez, Mari Carmen, Turner, Caroline, Zabel, Igor, \& Cassel, Valerie (2000). 'Beyond boundaries: rethinking contemporary art exhibitions'. Art Journal, 59, 4-21.

Mosquera, Gerardo (2001). 'Good-bye identity, welcome difference'. Third Text, 15, 25-32.

Mosquera, Gerardo (2002). 'Alien-own/own-alien: Globalization and cultural difference'. boundary, 2(29), $163-173$.

Peñaranda, Nelly, Correa, Daniel, Sánchez, Santiago, Montejo, Carolina, \& Guzmán, David (2014). Directorio Bogotá arte circuito. Bogotá: Fundación Arteria.

Peñaranda, Nelly, Guerrero, Diego, Sánchez, Santiago, Bray, Caroline Peña, \& Ferregán, Gustavo (2015). Directorio Bogotá arte circuito 2015-2016. Bogotá: Fundación Arteria.

Quemin, Alain (2013). 'International contemporary art fairs in a "Globalized" art market'. European Societies, 15, $162-177$.

Ramírez, Mari Carmen (1992). 'Beyond "The Fantastic": framing identity in U.S. exhibitions of Latin American Art'. Art Journal, 51, 60-68.

Regev, Motti (2008). 'Cultural uniqueness and aesthetic cosmopolitanism'. European Journal of Social Theory, 10, $123-138$.

Ruiz, Sandra Montoya (2017). Política exterior y diplomacia cultural: Hacia colombia en posconflicto. Bogotá: Universidad Católica de Colombia.

Serna, Julián Camilo (2009). 'El valor del arte. Hisotria de las primeras galerías de arte de Colombia (1948 - 1957)'. Ensayos. historia y teoría del arte, $17,61-84$.

Sooudi, Olga Kanzaki (2015). "Morality and exchange in the mumbai contemporary art world.". In Olav Velthuis, \& Stefano Baia Curioni (Eds.), Cosmopolitan canvases: The globalization of markets for contemporary art. Oxford: Oxford University Press.

Steiner, Lasse, Frey, Bruno S., \& Resch, Magnus (2013). "Home is where your art is: The home bias of art collectors." Wokring Paper by Department of Economics University of Zurich, Zurich. Zurich: University of Zurich.

Styhre, Alexander (2013). "The economic valuation and commensuration of cultural resources: Financing and monitoring the Swedish culture sector". Valuation Studies, 1, 51-81.

Urrutia, Miguel (2013). "Historia del Compromiso del Banco de la República con la Cultura". In Banco de la República (Ed.), 90 años del banco - Banco de la Reppũblica. Bogotá: Banco de la República.

Vatin, François (2013). 'Valuation as evaluating and valorizing'. Valuation Studies, 1, 31-50. 
Velthuis, Olav (2013). 'Globalization of markets for contemporary art'. European Societies, 15, 290-308.

Velthuis, Olav, \& Curioni, Stefano Baia (2015). 'Making markets global. '. In Olav Velthuis, \& Stefano Baia Curioni (Eds.), Cosmopolitan canvases. Oxford: Oxford University Press.

Whitelegg, Isobel (2013). "The bienal internacional de São Paulo: A concise history, 1951 - 2014". Perspective. Acutalité en histoire de l'art, 2.

Zuidervaart, Lambert (2011). Art in public. politics, economics, and a democratic culture. New York: Cambridge University Press.

Aerne, Annatina (2020). "Prestige in social dilemmas: A network analytic approach to cooperation among Bogotá's art organizations". Social Networks, 61, 196-209.

Annatina Aerne has earned a PhD in Organization and Culture from the University of St.Gallen (Switzerland) in 2019. Her dissertation analyzes the art scene in Bogotá, Colombia. It was awarded the prize for the best Swiss Dissertation on the Latin American region. She has published her research in Social Networks. Previously, she earned dual degrees in economics and political science from the University of St.Gallen and the Fletcher School of Law and Diplomacy (Tufts University, Boston, US). Annatina Aerne continues her work as a post-doctoral researcher at the University of Lausanne and serves in the University of St.Gallen's art committee. 